\title{
Ecological light measurement in forests using the light degradation effect in hydrogenated amorphous silicon (a-Si:H)
}

\author{
C Ammer ${ }^{1 *}$, G Krötz ${ }^{2}$ \\ 'Lehrstuhl für Waldbau und Forsteinrichtung der Ludwig-Maximilians-Universität München, \\ Hohenbachernstr. 22, 85354 Freising; \\ ${ }^{2}$ Daimler Benz AG, Postfach 800465, 81663 München, Germany
}

(Received 29 August 1996; accepted 17 February 1997)

\begin{abstract}
Summary - A method is presented for ecological light measurements in forests based on the principle that light produces electrically active defects within the mobility gap in semiconductors from hydrogenated amorphous silicon $(\mathrm{a}-\mathrm{Si}: \mathrm{H})$, causing measurable changes in the photoconductivity of the semiconductor. A comparison with measurements of the relative illuminance in mixed montane forests led to reasonable results. Suitability for field experiments, drawbacks and possible improvements of this low-cost integrating measurement method, which requires no external energy source, are discussed at length.
\end{abstract}

radiation / mixed forests / amorphous silicon

Résumé - Mesure de la lumière en forêts au moyen de la dégradation par la lumière du silicium amorphe hydrogéné (a-Si:H). Une méthode est présentée pour la mesure de la lumière en forêts, basée sur l'utilisation de semiconducteurs à base de silicium amorphe hydrogéné (a-Si:H). Une comparaison avec la mesure de l'éclairement relatif dans des forêts mélangées de montagne conduit à des résultats raisonnables. Les défauts et les améliorations possibles de cette méthode peu coûteuse pour des mesures intégrées, ne nécessitant pas de source extérieure d'énergie, sont discutés en détail par les auteurs.

lumière / forêts mélangées / silicium amorphe

* Correspondence and reprints

Tel: (49) 2161714686 ; fax: (49) 2161714646 


\section{INTRODUCTION}

Countless field tests have shown that under natural conditions the crucial factor in plant growth, ie, the factor determining photosynthesis capacity, in particular in conjunction with sufficient amounts of water and nutrients, is the radiation in the approximately $400-700 \mathrm{~nm}$ waveband (Fuchs et al, 1977; Benecke et al, 1981). As early as 1877 Hartig considered light as "the most important driving force in plant life", and numerous other scientists (see Zederbauer, 1907; Ramann, 1911; Knuchel, 1914) have since developed a great number of methods for measuring light (though first in the range sensitivity of the human eye, ie, $380-760 \mathrm{~nm}$ ). However, to this day light measurements in plants have always been considered "extremely complicated" (Anderson, 1964) and problematic on account of various details, which Brunner (1994) characterized as follows (see also Baldocchi and Collineau, 1994):

problem No 1: determination of direct and diffuse radiation;

problem No 2: spatial variation of radiation (affected by stand height and structure, or seasons);

problem No 3: time variation of radiation (daily, seasonal and long-term variations);

problem No 4: spectral changes in radiation within the stand;

problem No 5: correct evaluation of incident radiation with regards to photosynthesis.

The development of PAR-sensors for measuring photon fluxes based on surfaces with spectral sensitivities adapted to photosynthesis (McCree, 1972; Szeicz, 1975; Dohrenbusch, 1995; Dohrenbusch et al, 1995) has made available measuring instruments that deal effectively with the above problems and have become standard equipment in ecophysiological research (Brunner, 1994). However, for measurements in forests it is imperative that as many sample tests as possible be taken on account of the great spatial and time variations in radiation. Only with many sensors operating at the same time can variations in radiation be broken down into spatial and time components (Salminen et al, 1983). This is also the case for parallel measurements of many individual plants or parts of plants. In these cases "the expense of the logging and analysis data and the problems of security and signal loss due to damage to wires" (Newman, 1985) can restrict the use of the previously mentioned sensors. For these special purposes different low cost sensors have been developed in the past (eg, Friend, 1961; Newman, 1985; Chartier et al, 1989; Pontailler, 1990). In the following a report is given on first tests using a simple integrating measurement method without the use of an external energy source, which might also be suitable for these objectives.

\section{METHODS}

\section{Principle}

This method is based on the realization that light in amorphous semiconductors, such as hydrogenated amorphous silicon (a-Si:H), produces electrically active defects within the mobility gap. In the literature this is known as the Staebler-Wronski effect (Staebler and Wronski, 1977). The defects induced by the action of light are free silicon compounds not saturated by an hydrogen atom, the so-called 'dangling bonds'. The origin of 'dangling bonds' (DB) from intact silicon-silicon compounds has been the subject of numerous publications in recent years (see Stutzman et al, 1984). The present report describes how the accumulation of light-induced defects in a-Si:H was used for the development of a low-cost, integrating detector. The measuring unit is photoconductivity $\sigma_{\mathrm{ph}}$ of thin films coated with a-Si:H. For low light $\left(\leq 10 \mathrm{~mW} / \mathrm{cm}^{2}\right)$ photoconductivity is inversely proportional to the number of defects $N_{\mathrm{DB}}$ within the a-Si:H:

$$
\sigma_{\mathrm{Ph}} \sim 1 / N_{\mathrm{DB}}
$$


Thus, the variation in photoconductivity can be used as a unit for the number of defects induced by incident light.

The number of defects within the a-Si:H caused by illumination is proportional to the third root of illumination time $t$ and to the square of the third root of incident light intensity $l$ :

$$
\Delta N_{\mathrm{DB}} \sim t^{1 / 3} \times I^{2 / 3}
$$

Under certain preconditions the variations in photoconductivity permit conclusions as to the amount of light absorbed by a-Si:H. In the case of ecological light measurements intensities vary constantly and absolute values for absorbed radiation are difficult to obtain by this method. However, relative statements are possible on incident light intensity at different sampling points in the stand where similar variation profiles of light intensity at different levels exist.

\section{Material and sample preparation}

The degradation medium was thin films (approximately $0.5 \mathrm{~mm}$ ) from a-Si:H. Hydrogenated amorphous silicon is a semiconductor with a mobility gap of about $1.7 \mathrm{eV}$ and is deposited from silan in a plasma process (PECVD-process, ie, plasma enhanced chemical vapour deposition) (LeComber and Spear, 1985). The deposition is made onto flat glass screens made from corning glass (CG 7059) approximately $50 \times 50$ $\mathrm{mm}$ and $0.8 \mathrm{~mm}$ thick. In an evaporation system 16 aluminium contact pairs about $0.3 \mathrm{~mm}$ thick are applied with the aid of steel shadow masks. The area for each contact is about $2 \times 5 \mathrm{~mm}$ and the contact pairs are placed at a distance of $1 \mathrm{~mm}$ from each another. After the evaporation process the glass substrate is divided with a diamond cutter into samples approximately $10 \mathrm{~mm}^{2}$. Each square holds a contact pair between which the photoconductivity of the thin a-Si:H film can be measured. Figure 1 is a schematic representation of the samples for photoconductivity measurements and contact generation during the measuring process.

\section{Measuring procedure}

The unit determining light absorption by the samples is the change in photoconductivity. This has to be determined before and after exposing the samples to light and is carried out according to the set-up shown in figure 2 . This consists of a white light source (halogen lamp, $250 \mathrm{~W}$ ), a lens, a ground glass screen for homogeneous illumination of the samples and a sample clamp. The latter is designed to permit a quick exchanging of samples so that even large numbers of samples can be measured within a reasonably short period of time.

Upon completion of both measurements the radiation absorption of a sample can be expressed in terms of the relative change in sample photoconductivity:

$$
\Delta N_{\mathrm{DB}}(\%)=\frac{\frac{1}{\sigma_{\mathrm{Ph}_{t+1}}}-\frac{1}{\sigma_{\mathrm{Ph}_{t}}}}{\frac{1}{\sigma_{\mathrm{Ph}_{t}}}}
$$

where: $\sigma_{\mathrm{Ph}}=k\left(J_{\text {light }}-J_{\text {dark }}\right) ; k=$ geometry factor; $J_{\text {light }}=$ light current; $J_{\text {dark }}=$ dark current; $t=$ time before exposure to light; $t+1=$ time after exposure to light.

The photoconductivity measurements were performed using a Hewlett Packard picoamperemeter HP 4140B. A constant voltage of $100 \mathrm{~V}$ was applied to the aluminium contacts of the samples during the current measurements.

\section{Experimental test in forest}

Immediately after completing the first measuring step four samples were placed in a $5 \times 4 \mathrm{~cm}$ plexiglass box, which was sealed water tight with silicon paste, wrapped in aluminium foil and thus transported, in total darkness, to a research area pursued by the Chair for Silviculture and Forest Inventory ( 80 samples in 20 boxes in total). This is a mixed montane forest, about 110 years old with a stand consisting of spruce (Picea abies (L) Karst), fir (Abies alba Mill), beech (Fagus sylvatica $\mathrm{L}$ ) and maple (Acer pseudoplatanus $\mathrm{L}$ ) $(45,30,20$ and $5 \%$, respectively) at about 950 $m$ above sea level near the small town of Ruhpol$\operatorname{ding}\left(47^{\circ} 45^{\prime} \mathrm{N}, 13^{\circ} 39^{\prime} \mathrm{E}\right.$, Germany).

The entire stand had been divided into ten subplots, which showed distinct variations in canopy density, as a consequence of different silvicultural treatments. This stand is part of an interdisciplinary research programme started in 1976 to investigate the effects of different ecological factors on natural regeneration (see Burschel et al, 1992). Luxmeter data at $1.5 \mathrm{~m}$ above 


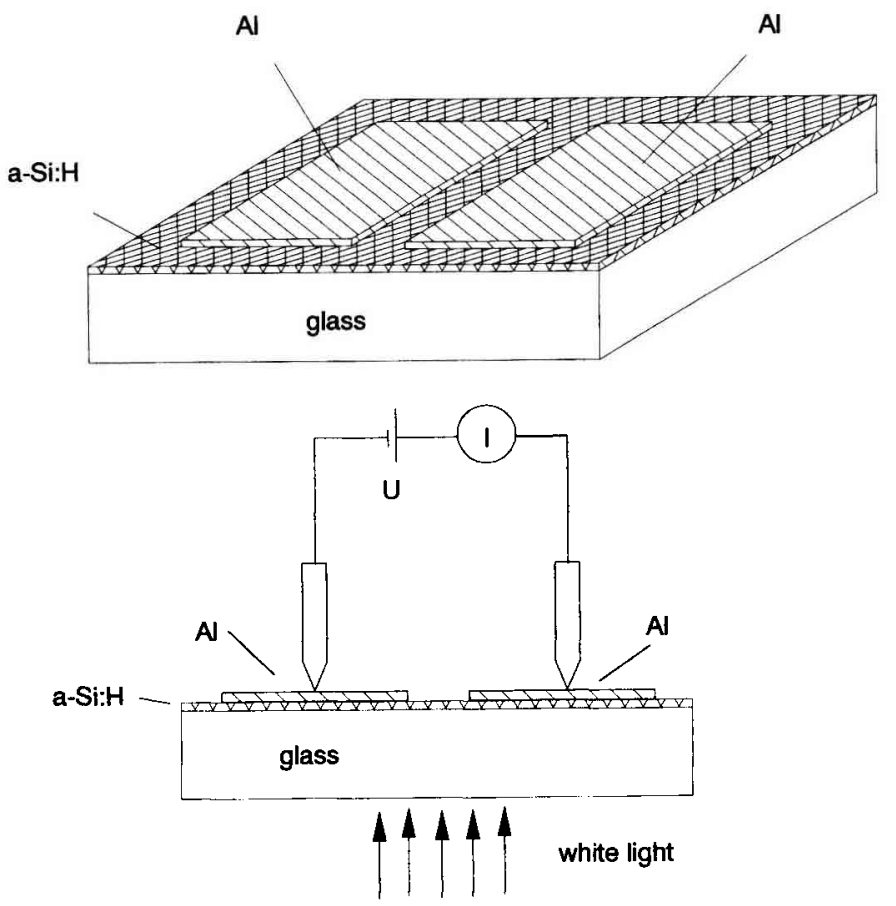

Fig 1. Schematic sketch of sample geometry and electrical measuring circuit.

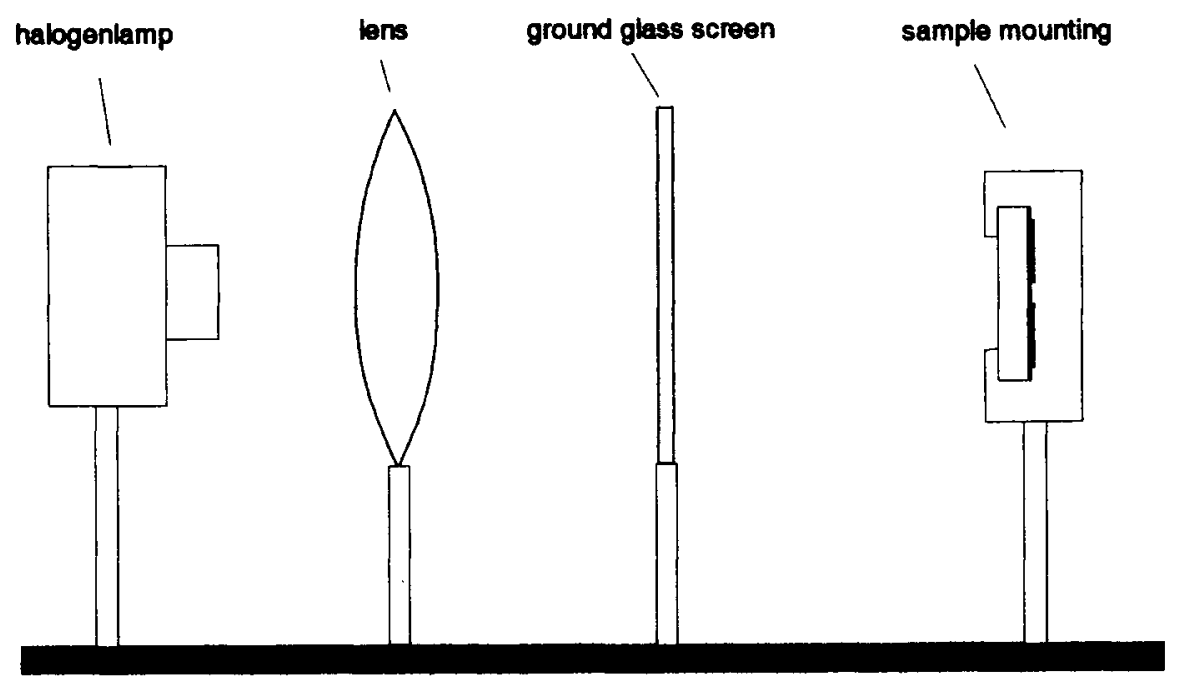

Fig 2. Experimental set-up for photoconductivity measurements. 
the ground for a number of the permanently marked sample points (centre points of $1 \mathrm{~m}^{2}$ circular sampling units for natural regeneration inventories) were available from the last inventory carried out on these plots in 1993. These had been made with instruments by BBC-Goerz-Metrawatt in Nürnberg. Since relative values had proved to be independent of exterior brightness in diffuse light only (Mitscherlich et al, 1967; von Lüpke, 1982; Dohrenbusch, 1987) measurements were made exclusively under overcast skies in August between 11 am and 2 pm Central European Summer Time. Taking into account the simultaneous measurements (by radio signal) on open spaces, relative illuminance was calculated for each sampling point as

$$
\mathrm{RI}(\%)=\frac{k \operatorname{Lux}_{\text {stand }}}{k \operatorname{Lux}_{\text {open space }}} \times 100
$$

The plexiglass boxes containing the samples were mounted on wooden poles $1.5 \mathrm{~m}$ above the ground at the centre of 20 selected circular sampling units. In order to cover the greatest possible range of irradiance, five boxes (each with four samples) were exposed on subplots that had been subjected to different silvicultural treatments (table I ). A few sampling units with identical light conditions were selected for a crosscheck of measuring results.

As photoconductivity is known to remain unaffected by further radiation once maximum defect density has been reached (Park et al, 1989) we tried to find out in a preliminary test whether this saturation point in defect density would be reached within a period of 6 weeks under exclusively diffuse radiation conditions (samples exposed to the north of a long-term shading wall). As figure 3 shows, this was not the case. From the assumption that this point would have been rea-

Table I. Mean and standard deviation of the relative change of defect density (1994) and corresponding values of the relative illuminance (RI) (1993).

\begin{tabular}{lcccc}
\hline Silvicultural treatment & Sampling unit & \multicolumn{2}{c}{$\Delta N_{D B}(\%)$} & $R I(\%)$ \\
\hline & & $\bar{X}$ & $s$ & \\
Control & 1 & 1085.50 & 138.08 & 5.68 \\
$\quad$ (no intervention) & 2 & 1226.50 & 327.30 & 5.10 \\
& 3 & 937.75 & 272.42 & 6.12 \\
& 4 & 919.25 & 299.37 & 5.95 \\
& 5 & 1004.50 & 90.63 & 5.81 \\
Light shelterwood cutting & & & & \\
(reduction of basal area by 30\% in & 6 & 1698.25 & 575.87 & 11.58 \\
1976) & 7 & 1522.25 & 214.75 & 11.48 \\
& 8 & 1661.25 & 272.54 & 22.22 \\
& 9 & 1490.25 & 400.51 & 11.64 \\
Heavy shelterwood cutting & 10 & 1555.25 & 339.51 & 22.22 \\
(reduction of basal area by 50\% in & 12 & & & \\
1976) & 11 & 2305.25 & 383.87 & 36.70 \\
& 13 & 2066.25 & 114.06 & 36.91 \\
& 14 & 2463.25 & 266.73 & 32.12 \\
Clear cutting & 15 & 2078.50 & 227.55 & 19.71 \\
(elimination of whole stand by one & 17 & 2096.75 & 280.84 & 21.70 \\
cutting operation in 1976, & 18 & & & \\
covered since then with natural & 19 & 1780.25 & 298.23 & 23.26 \\
regeneration of mainly sycamore maple) & 20 & 2747.25 & 165.12 & 64.29 \\
\hline & 16 & 3166.00 & 828.77 & 78.95 \\
\hline
\end{tabular}




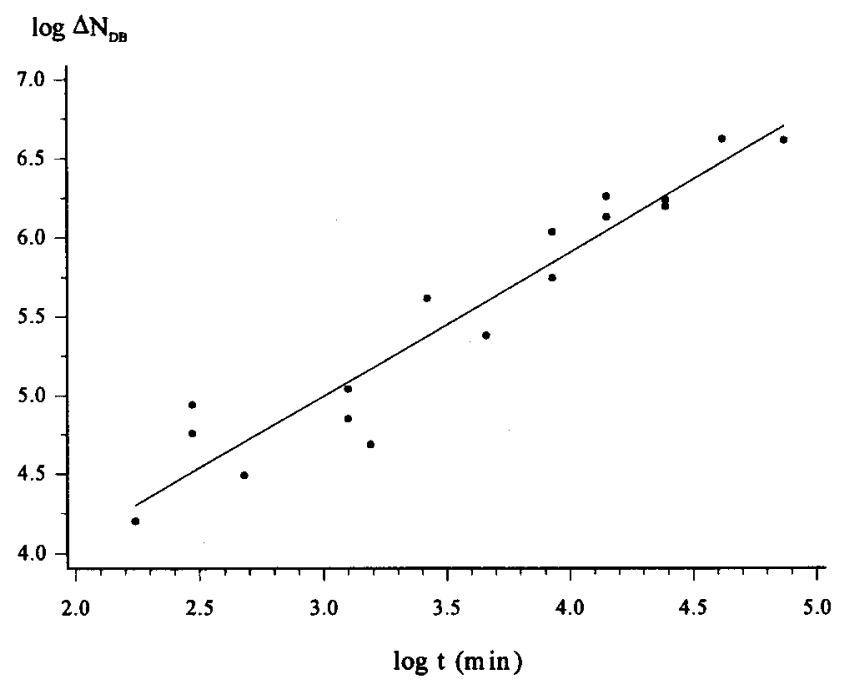

Fig 3. Relative change in defect density $\left(\Delta N_{\mathrm{DB}}\right)$ plotted against time. Only diffuse radiation is taken into account.

ched under more intense radiation conditions, ie, with direct radiation components, a test period of about 5 weeks for the actual tests was deduced. After exposure on site for approximately 53300 min (from 29 July to 4 September 1994) the samples were collected, blacked out again and taken back to the laboratory for renewed measurements of photoconductivity.

\section{RESULTS AND DISCUSSION}

Table I represents mean values and standard deviations obtained from four samples each, their respective sites and the comparative values for relative illuminance $(\mathrm{RI})$ measured in 1993.

As is evident from figure 4 , which plots the variation coefficient for measured changes, measurements proved to be relatively uniform for the entire light intensity range sampled in this investigation.

Figure 5 shows that the determination of relative variations in photoconductivity is suitable also for describing the increase in relative illuminance with decreasing canopy density as measured by a luxmeter. This is particularly true if the two measuring points exposed to the most intense radiation are ignored (black line). A linear relationship then exists between the two measuring values. The distinct change in the regression curve (broken line) obtained when all the measuring points are taken into account can probably be explained by the fact that the samples at the measuring points exposed to the greatest amount of radiation had already reached maximum defect density before the tests had been completed and, thus, there was no further appreciable radiation effect.

However, it must not be overlooked that, apart from the common tendencies described above, the two measuring methods, provided maximum defect density of the samples is not reached, also show ranges with great, system-related variations in measuring results. In particular in the very densely to densely canopied range there were diffe- 


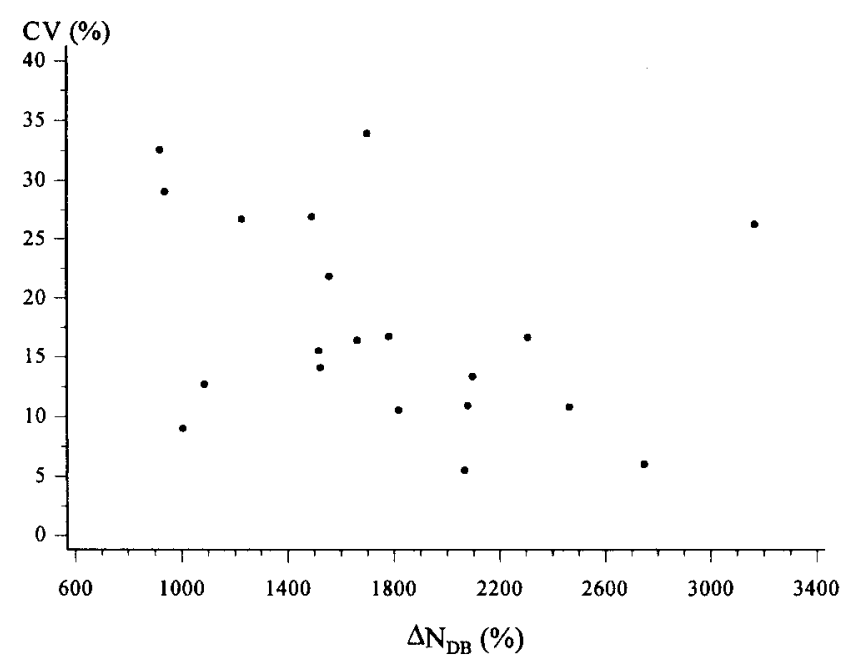

Fig 4. Coefficient of variation (CV) of $\Delta N_{\mathrm{DB}}$ based on four samples each.

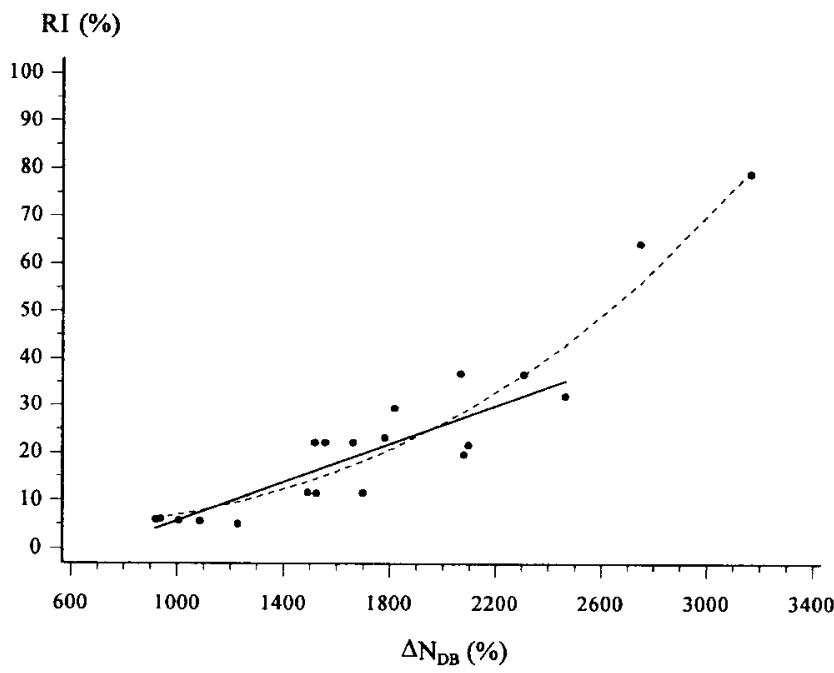

Fig 5. Relationship of the relative change in defect density $\left(\Delta N_{\mathrm{DB}}\right)(1994)$ to relative illuminance (1993); for explanations see text (broken line: $y=3.1145+6.0497 \times 10^{-8} x^{2.6}$, adj. $r^{2}=0.90, F=168.79$, Prob $>F=0.0001$; black line: $y=-14.48+0.02 \mathrm{x}$, adj. $r^{2}=0.75, F=48.75$, Prob $>F=0.0001$ ).

rences in the relative changes in photoconductivity for similar relative illuminance conditions. This suggests the influence of direct radiation from sunflecks, which was only taken into account in our method. This predominantly direct radiation component 
(Smith and Morgan, 1981) can be the source of considerably increased absorbed radiation at individual sample points (Gross and Chabot, 1979; Pearcy et al, 1987; Chazdon, 1988; Pearcy, 1988).

An indication that our method actually permits a sufficient description of radiation conditions crucial to plant photosynthesis, by taking into account the direct radiation component, is given by the comparison of two sample points at the moderate shelterwood subplot, for which almost identical relative illuminance $(\mathrm{RI})$ values had been determined (sample points Nos 6 and 9, data not shown). Sample point No 6 was identified as having the more favourable radiation conditions based on the measured changes in photoconductivity and had both considerably greater amounts of biomass and higher plant density than sample point 9 . Further comparisons of this kind were not possible owing to a lack of plants (in very dark ranges) or browsing by deer (numerous sample points had no protective fencing).

No conclusive assessment of the above method for ecological light measurements is possible owing to the very few measurements, the lack of comparison with measurement data of identical observation periods and data, eg, from PAR-sensors (regrettably not available). The latter objection is very grave, since authors such as Pearcy (1989) emphasise that measurements of photosynthesis-relevant radiation on a photometric basis is worthless. In spite of this contradiction Dohrenbusch (1987) and Brunner (1993) could show that for ecological, but not for physiological, purposes the measurement of the relative illuminance is sufficient in many cases. Although the use of luxmeters for calibration restricts a complete dicussion of problems Nos 1, 3 and 4 outlined in the Introduction, in the following section a preliminary evaluation of the suitability of our method is tested.

\section{Determination of diffuse and direct radiation components}

In contrast to the method of Wagner and Nagel (1992) and Wagner (1994), who determine solar radiation from fish-eye photos with imaging software, our system regrettably allows no break-down into diffuse and direct radiation components. A different effect of diffuse and direct radiation on the silicon samples could be caused by the fact that in the case of diffuse incident light interference phenomena on the thin a$\mathrm{Si}: \mathrm{H}$ films might have to be taken into account. This could perhaps be avoided if the a-Si:H films are deposited onto ground substrates. It is an advantage, however, that the changes in photoconductivity of the samples are the result of the actual total incident radiation. This implies that it could be possible to discover factors that affect plant growth that are being overlooked when one radiation component only is being taken into account throughout. An example of this could be the effect of topography, which only affects the direct radiation component (Baumgartner, 1960; Biederbick, 1992).

As in other integrating measurement systems, it is also conceivable for this method that the sum of light energy measured is not necessarily identical to the light energy actually used by the plant (Dohrenbusch et al, 1995). Thus, while it is possible to measure too little (Young and Smith, 1979) or excess radiation (photoinhibition, heat stress) (Chazdon, 1988), plants may not be able to fully use either for photosynthesis. Errors caused by the above should, however, not be too great, at least not in the case of intense radiation, since a linear increase in photosynthetic response in relation to available light is assumed to exist (Larcher, 1994) in plant stands in contrast to individual leaves. 


\section{Spatial and time variations}

The determination of spatial variations of the light regime in plant stands could be one field of application where our method is expected to have considerable advantage over conventional methods. In 1911 Ramann emphasized that: "Light measurements in forests are subject to constantly changing illumination and require a great number of individual measurements rather than great accuracy". Since the size of the sample test and the duration of the measuring period have considerable influence on the variations in the measuring data (Gay et al, 1971; Johannson, 1987) it is recommended for investigations using PAR-sensors that these be moved through the stand on tracks or conveyor belts ('moving sensors') (Mukammal, 1971; Szeicz, 1975; Baldocchi et al, 1986). Salminen et al (1983), however, pointed out that this does not permit a breakdown into spatial and time variations, in contrast to many sensors measuring simultaneously. This could, however, be achieved with our method (of course not in the case of short-term spatial variations) and, moreover, with an optional alignment in any direction. For ecological investigations it is therefore conceivable that, eg, radiation absorption of a great number of individual plants or parts of plants at different heights from the ground can be measured and compared. Also, the simultaneous investigation of seasonal variations in different types of forest (Chazdon, 1988) would be possible.

\section{Spectral sensitivity}

Ever since the first light measurements were performed in forests, it has always been pointed out that the measuring system must record not only the intensity, but also the quality of radiation (Zederbauer, 1907; Coombe, 1957; Anderson, 1964). This is particularly important when data on radiation are seen in the context of plant photo- synthesis (Langholz and Häckel, 1985). Figure 6 shows the relative amount of optical absorption by the amorphous silicon (right scale) and the amount of transmission by the plastic boxes in which the silicon cells had been encased (left scale). It is obvious, that these two components alone do not warrant a good approach to the spectral efficiency of photosynthesis. Above all the short-wave break-off edge of sensor reaction at about $400 \mathrm{~nm}$ has to be achieved by means of filters. The simplest way to realize this could be to use containers for the a-Si:H samples that do not permit light transmission below $400 \mathrm{~nm}$. The ones used here were already transmissive at $300 \mathrm{~nm}$ (fig 6). The availability of low-cost sample containers with the requisite transmission properties needs to be checked. If none are available, it is conceivable that thin a-Si:H filtering layers could be deposited on the other side of the samples. This could be carried out in the same deposition system used for the a-Si:H films.

Another problem is that the absorption of the thin a-Si:H film is related to the wave length, which leads to an increasingly irregular absorption behaviour with increasing sample thickness and decreasing wave length. Modification of layer thickness or bandgap by alloying with carbon might solve this problem.

\section{Measuring period}

As diffuse radiation components vary only very slightly in the course of a vegetation period while direct ones undergo very great changes (Anderson, 1970), daily totals are not very effective and their validity is very inferior to integrating measurement methods applied over longer periods of time. The collection of data over longer periods of time is also possible with the method presented here. However, since the maximum defect density of samples is reached more quickly under intense radiation conditions, 


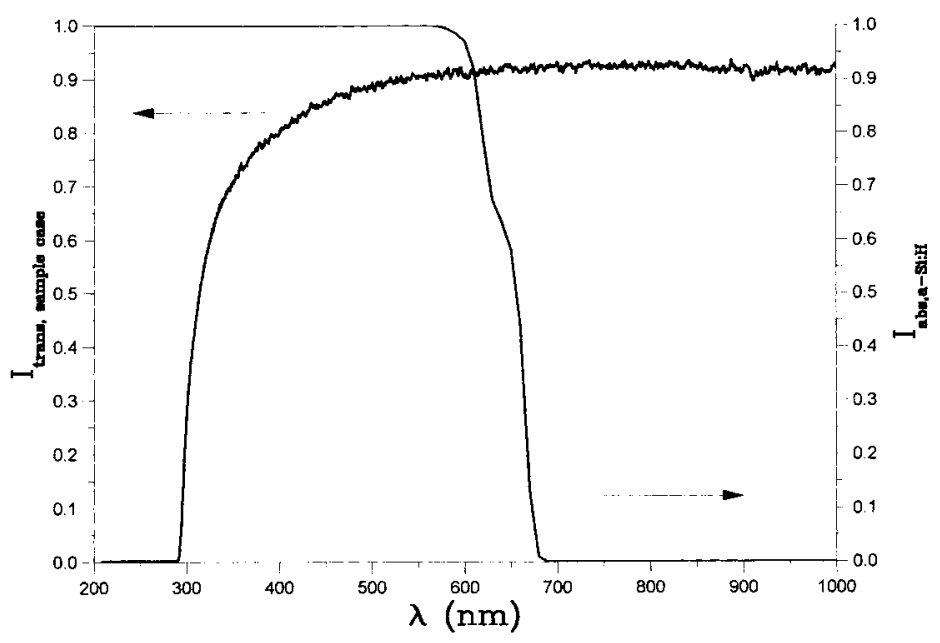

Fig 6. Optical transmission and absorption behaviour of the sample boxes (left scale) and the amorphous silicon films (right scale), respectively. Reflection losses and optical interferences of the latter are not taken into account.

the measuring duration largely depends on local conditions. In any case the measuring period will be at least several weeks and thus also helps to mitigate one severe drawback of our method. The conversion of the number of defects into energy units or photon flux densities is not possible, while data on the relative change in photoconductivity are neither useful nor do they permit comparisons. It is therefore necessary to rely on relative values that describe the relative changes determined in the stand in relation to conditions on a reference area. While comparisons between relative values of areas of different local climate are not satisfying, in addition Anderson (1964) recommends listing the original measured absolute values. Moreover, it is disadvantageous that relative values, unless referring to the diffuse radiation components only, are highly dependent on exterior brightness (Mitscherlich et al, 1967; Brunner, 1993). However, errors arising from this should be almost negligible when taking measurements over lengthy periods of time where different exte- rior brightness conditions are being taken into consideration.

\section{Comparison with other low-cost sensors or methods}

As mentioned in the Introduction, some other cheap methods for measuring light in the field already exist. More than 30 years ago Friend (1961) provided a description of the use of light-sensitive diazo paper. However, the correct assessment of this method requires a specific interpretation (Bardon et al, 1995). Recently Newman (1985), using silicon photocells and Pontailler (1990) who employed a gallium arsenide photodiode, presented new methods that allow sufficiently accurate measurements. However, both methods are restricted in the number of sensors measuring simultaneously, and depend, in the case of the gallium arsenide photodiode, on an external energy source. This also applies to the methods of Chartier et al (1989) and Muleo et al (1993), who 
also used amorphous silicon, although in a deviating way of measurement (photoelectric current compared to changes in photoconductivity (as in this paper)). However, in particular Chartier et al (1989) realized a number of tests also necessary for the method presented here. This relates above all to results concerning the cosine response and temperature dependence. With regards to both factors Chartier et al (1989) underlined the potential of amorphous silicon cells for ecological light measurements. If these results can be confirmed, our method is probably favourable. As a-Si:H thin films are used now in a variety of products, like solarcells, scanners, etc, commercial manufacturers are on the market. Depending on numbers we would expect that samples could be bought in bulk at low prices from commercial suppliers. A laboratory equipment for producing the cells would cost between 300000 and 800000 DM.

As the light generated defects in the a$\mathrm{Si}: \mathrm{H}$ layers can be annealed at strongly elevated temperatures, the samples are principally renewable. Nevertheless, irreversible processes during annealing could lead to a different starting position compared to unused samples. As the samples are expected to be quite cheap if produced commercially, it would be recommended to always use fresh and unused samples.

\section{CONCLUSIONS}

While the development of methods such as PAR-sensors or the computerized evaluation of hemispherical photographs (Wagner and Nagel, 1992; Wagner, 1994; Easter and Spies, 1994) nowadays permits the determination of absolute energy values or photon flux densities, and is considered suitable for radiation evaluation in forests, there are still only a few simple integrating measurement methods for the simultaneous determination of the radiation utilized by plants at any number of sample points on a given area or within a single plant. In the method presented here spectral sensitivity of the sensors, the use of relative values and the undefined maximum possible measuring period still need to be improved or they represent certain drawbacks. However, the method could be a step towards another sufficiently accurate method to warrant the "compromise between accuracy and practicability" in field light measurements demanded by Anderson (1964).

\section{ACKNOWLEDGEMENTS}

The authors wish to thank Dr Müller (DaimlerBenz AG) for his suggestion, made many years ago, to use the Staebler-Wronski effect as the integrating detection principle for radiation as well as for his interest in and support of this study. Thanks are also due to Mr Legner for his assistance with the design and construction of the sample clamping device, to Prof Dr H Mayer, Dr S Wagner and anonymous reviewers for their critical and very helpful comments. Last but not least many thank to Mrs H Meier for the English translation of this manuscript.

\section{REFERENCES}

Anderson MC (1964) Light relations of terrestrial plant communities and their measurement. Biol Rev 39, 425-486

Anderson MC (1970) Interpreting the fraction of solar radiation available in forest. Agric Meterorol 7, 1928

Baldocchi D, Collineau S (1994) The physical nature of solar radiation in heterogeneous canopies: spatial and temporal attributes. In: Exploitation of Environmental Heterogenity by Plants: Ecophysiological Process above-and below Ground (MM Caldwell. RW Pearcy, eds), Academic Press, San Diego, 21-71

Baldocchi D, Hutchison B, Matt D, McMillen R (1986) Seasonal variation in the statistics of photosynthetically active radiation penetration in an oak-hickory forest. Agric Forest Meteorol 36, 343-361

Bardon RE, Countryman DW, Hall RB (1995) A reassessment of using light-sensitive diazo paper for measuring integrated light in the field. Ecology 76 , 1013-1016 
Baumgartner A (1960) Gelände und Sonnenstrahlung als Standortfaktor am Gr Falkenstein. Forstw $\mathrm{Cbl}$ $79,286-297$

Benecke U, Schulze E-D, Matyssek R, Harranek WM (1981) Environmental control of $\mathrm{CO}_{2}$-assimilation and leaf conductance in Larix decidua Mill. I. A comparison of contrasting natural environments. Oecologia 50, 54-61

Biederbick K-H (1992) Die direkte Sonnenstrahlung als Standortfaktor. Forstarchiv 63, 131-136

Brunner A (1993) Die Entwicklung von Bergmischwaldkulturen in den Chiemgauer Alpen und eine Methodenstudie zur ökologischen Lichtmessung im Wald. Forstl Forschungsberichte, Nr 128

Brunner A (1994) Ökologische Lichtmessung im Wald. Forstarchiv 65, 133-138

Burschel P, El Kateb H, Mosandl R (1992) Experiments in mixed mountain forests in Bavaria. In: The Ecology and Silviculture of Mixed-species Forests (MJ Kelty, BC Larson, CD Oliver, eds), Kluwer Academic Publishers, Dordrecht, 183-215

Chartier M, Bonchretien P, Allirand JM, Gosse G (1989) Utilisation des cellules au silicium amorphe pour la mesure du rayonnement photosynthétiquement actif (400-700 nm). Agronomie 9, 281-284

Chazdon RL (1988) Sunflecks and their importance to forest understorey plants. Adv Ecol Res 18, 163

Coombe DE (1957) The spectral composition of shade light in woodlands. $J$ Ecol 45, 823-830

Dohrenbusch A (1987) Kann die, ,relative Beleuchtungsstärke" die Lichtverhältnisse im Wald zuverlässig charakterisieren? Forstarchiv 58, 2427

Dohrenbusch A (1995) Überlegungen zur Optimierung der Strahlungsmessung im Wald. Allg Forstu J Ztg 166, 109-114

Dohrenbusch A, Kranigk J, Pryor D (1995) Entwicklung und Bau eines Lichtmeßgerätes zur Erfassung der photosynthetisch nutzbaren Strahlung. Allg Forst-u J Ztg 166, 154-160

Easter MJ, Spies TA (1994) Using hemispherical photograph for estimating photosynthetic photon flux density under canopies and in gaps in Douglas-fir forests of the Pacific Northwest. Can J For Res 24, 2050-2058

Friend DTC (1961) A simple method of measuring integrated light values in the field. Ecology 42,577 580

Fuchs M, Schulze E-D, Fuchs MJ (1977) Spatial distribution of photosynthetic capacity and performance in a mountain spruce forest of Northern Germany. Oecologia 29, 329-340

Gay LW, Knoerr KR, Braaten MO (1971) Solar radiation variability on the floor of a pine plantation. Agric Meterorol 8, 39-50
Gross LJ, Chabot BF (1979) Time course of photosynthetic response to changes in incident light energy. Plant Physiol 63, 1033-1038

Hartig T (1877) Photometrisches. Allg Forst- u J Ztg 53, 35-36

Johannson T (1987) Irradiance in thinned Norway spruce (Picea abies) stands and the possibilities to prevent suckers of broadleaved trees. For Ecol Manage 20, 307-319

Knuchel H (1914) Spektrometrische Untersuchungen im Walde. Mitt d Schweiz Centralanstalt fd Forstl Versuchswesen 11, 1-94

Langholz H and Häckel H (1985) Messungen der photosynthetisch aktiven Strahlung und Korrelationen mit der Globalstrahlung. Meteorol Rdsch 38, 75 82

Larcher W (1994) Ökophysiologie der Pflanzen, Leben Leistung und Strßbewältigung in ihrer Umwelt, 5. Völlig neubearb Auflage. Eugen Ulmer, Stuttgart

LeComber PG, Spear WE (1985) Doped amorphous semiconductors in amorphous Semiconducters. In: Topics in Applied Physics (MH Brodsky, ed), Springer, Berlin, 251-285

Lüpke B von (1982) Versuche zur Einbringung von Lärche und Eiche in Buchenbestände. Schriften a d Forstl Fakultät der Universität Göttingen u d Niedersächsischen Forstl Versuchsanstalt, Bd 74

McCree KJ (1972) Test of current definitions of photosynthetically active radiation against photosynthesis data. Agric Meterorol 10, 443-453

Mitscherlich G, Künstle E, Lang W (1967) Ein Beitrag zur Frage der Beleuchtungsstärke im Bestand. Allg Forst- u J Ztg 138, 213-223

Muleo R, Tellini A, Masetti C, Morini S (1993) Low cost sensors to measure solar radiation in woody plant communities. Adv Hort Sci 7, 117-121

Mukammal El (1971) Some aspects of radiant energy in a pine forest. Arch Met Geoph Ser B 19, 29-52

Newman SM (1985) Low cost sensor integrators for measuring the transmissivity of complex canopies to photosynthetically active radiation. Agric For Meterol 35, 243-254

Park HR, Liu JZ, Wagner S (1989) Saturation of the light-induced defect density in hydrogenated amorphous silicon. Appl Phys Lett 55, 2658-2660

Pearcy PW (1988) Photosynthetic utilisation of lightflecks by understory plants. Aust J Plant Physiol 15, 223-238

Pearcy PW (1989) Radiation and light measurement In: Plant Photosynthetical Ecology (RW Pearcy, JR Ehleringer, HA Mooney, PW Rundel, eds), Chapman \& Hall, 97-116

Pearcy RW, Chazdon RC, Kirschbaum MUF (1987) Photosynthetic utilisation of lightflecks by tropical forest plants. In: Progress in Photosynthesis Research, vol IV (J Briggens, ed), Martinus Nijhoff Publishers, Dordrecht, 257-260 
Pontailler J-Y (1990) A cheap quantum sensor using a gallium arsenide photodiode. Functional Ecol 4, $591-596$

Ramann E (1911) Lichtmessungen in Fichtenbeständen. Allg Forst - $u J$ Ztg 87, 401-406

Salminen R, Hari P, Kellomäki S, Korpilalti E, Kotiranta M, Sievänen R (1983) A measuring system for estimating the frequency distribution of irradiance within plant canopies. J Appl Ecology 20, 887-895

Smith H, Morgan DC (1981) The spectral characteristics of the visible radiation incident upon the surface of the earth. In: Plants and the Daylight Spectrum (H Smith, ed), Academic Press, London, 3-20

Staebler DL, Wronski CR (1977) Reversible conductivity changes in discharge-produced amorphous Si. Appl Phys Lett 31, 292-294

Stutzmann M, Jackson WB, Tsai CC (1984) Lightinduced metastable defects in hydrogenated amorphous silicon: A systematic study. Phys Rev B 32, 23-47
Szeicz G (1975) Instruments and their exposure. In: Vegetation and the Atmosphere Vol 1 Principles (JL Monteith, ed), Academic Press, London, 229 273

Wagner S, Nagel J (1992) Ein Verfahren zur PC - gesteuerten Auswertung von Fish - eye - Negativfotos für Strahlungsschätzungen. Allg Forst- $u \mathrm{~J} \mathrm{Ztg}$ $163,110-116$

Wagner S (1994) Strahlungsschätzung in Wäldern durch hemispärische Fotos-Methode und Anwendung. Ber d Forschungszentrums Waldökosysteme Reihe A, Bd 123

Young DR, Smith WK (1979) Influence of sunflecks on the temperature and water relations of two subalpine understory congeners. Oecologia 43, 195-205

Zederbauer E (1907) Das Lichtbedürfnis der Waldbäume und die Lichtmessmethoden. Cbl Ges Forstwesen 33, 325-330 